\title{
Judicial Corruption: A Paradox of the Criminal Justice System in the Law Enforcement on Corruption Crime in Indonesia
}

\author{
Slamet Haryadi ${ }^{1}$, Nurlaili Husna ${ }^{2}$ \\ \{slametharyadisukandar@yahoo.com ${ }^{1}, \underline{\text { nurlaili.husna1053@students.unila.ac.id²\} }}$ \\ ${ }^{1}$ Faculty of Law and Social Science, Muhammadiyah University of Kotabumi, Indonesia \\ ${ }^{2}$ Faculty of Law, University of Lampung, Bandar Lampung, Indonesia
}

\begin{abstract}
The criminal justice system in Indonesia today illustrates a paradoxical situation in law enforcement on corruption. On the one hand, the society have great expectation that the criminal justice system can eradicate corruption, on the other hand, law enforcement officers such as national police investigator, public prosecutor, and judge, in their own way continue to weaken law enforcement by committing judicial corruption. The basic problem is how the natures of characters of judicial corruption crime that lead to the paradox of law enforcement on corruption are. Judicial corruption in the criminal justice system can be interpreted as a crime committed by law enforcement officers, such as police investigator, public prosecutor, or judge, who is handling a corruption case, by plotting the case as if the suspect was innocent though he/she is guilty, it is then plotted as if it was a trifle. Therefore, the legal process is reduced as a means of gaining benefit and personal wealth. Some of them are just formal procedure for implementing the law. This is the paradox of the criminal justice system in law enforcement on corruption in Indonesia. Judicial corruption has mostly affected law enforcement officers' life by deviating from law enforcement. The results of the analysis, the natures of judicial corruption crime committed by law enforcement officers in the criminal justice system form mental constructions which tend to damage and weaken the law, namely: (1) disregard of the law, (2) cherry-picking, (3) limiting the legal's reach, (4) narrowing the meaning of the law, (5) exploiting the severity of the sentence.
\end{abstract}

Keywords: Crime; Judicial Corruption; Criminal Justice System

\section{Introduction}

Transparency International (TI) defines corruption as "the abuse of entrusted power for private gain ." (TI) based on a survey in 2017, Indonesia's Corruption Perception Index/CPI (corruption perception index) was at a score of 37 and ranked 96th out of 180 countries. CPI is very important indicator which can reflect inhabitants' opinions (perception of corruption). Thus, Indonesia is considered highly corrupted while corruption is a crime against humanity which destroys the country and infects every level of government. However, the eradication of corruption by the criminal justice system has not progressed (stagnant). Even, the biggest corruption practices in Indonesia, besides being committed by executive and legislative sectors, it is also committed by judicial institution. 
Data sourced from Corruption Eradication Commission (KPK) that in 2017-2018 there were 18 governors and 75 regents/mayors caught in corruption , 81 people from the central to regional representatives and law enforcement officers in the criminal justice system of all hierarchy in the last five years, 28 law enforcement officers, 17 judges and two judges in the South Jakarta District Court, are caught in the act (OTT) by KPK, while the report/complaint to the Judicial Commission (Komisi Yudisial) and Supervisory Commission of Supreme Court submitted to the Honorary Judges' Council for bribery and gratuity of 22 people. The criminal justice system according to Mardjono and Muladi is a means of law enforcement, ideally being a stronghold and preventing corruption. However, in many corruption cases decided by the Corruption Court in Indonesia show the fact that the law enforcement officers do not fully carry out their duty and authority and tend to create deviance. Previous scholarship has consistently shown that low self-control is the key in understanding deviance. Low selfcontrol serves as a dispositional prerequisite for engaging in norm-violating or criminal behavior. Thus, some of its authority has been reduced as a procedural legal activity, while some gain benefit by corruption and bribery from the cases handled.

Bribery is common form of corruption. Bribes reported, the number of prosecutions brought or court cases directly linked to corruption. Additionally, the law enforcement officer who commits bribery is the same as committing two crimes at once, namely (1) enriching themselves, sucking nation's money by manipulating its institution; (2) damaging the image of the institution by subverting noble values, truth, honesty, and justice. Various terms are used to explain bribery in law enforcement such as judicial mafia, legal mafia, judicial corruption, and others. All these terms are related to bribery and considered as condemned crime because it destroys the pillars part of democratic government and legal state.

In short, the current condition of the criminal justice system in Indonesia illustrates a paradox in law enforcement on corruption. While the society have great expectation of the criminal justice system, however, the law enforcement officers continue to weaken law enforcement by committing judicial corruption.

\section{Problem}

Based on the background, the basic problem intended to find out is how the natures or character of judicial corruption crime that leads to a paradox of law enforcement on corruption are.

\section{Research Method}

The subjects of the research are the law enforcement officers from police investigator, public prosecutor, judge, and advocate, as well as some people who have ever experienced and interacted socially in matters of corruption. The research on judicial corruption crime is conducted in jurisdiction of Tanjung Karang Corruption Court, Bandar Lampung because Lampung is one of the regions that has received national attention related to the practice of judicial corruption. The data collected from observation, interview, and documents analysis from law enforcement officers (police officer, prosecutor, judge, and lawyer) and several informants who are involved in judicial corruption practice, as well as collecting of legal 
action products from law enforcement officer such as the letter of detention suspension, indictment, letter of demand, and court decision letter.

Interpretation and reflection of legal hermeneutics is used to understand the context of the conversation and its legal context in analyzing the meanings of all aspects that are the essence of the conversation and the legal text of the legal action of officer, whereas to guarantee the credibility of data/fact, a source triangulation technique is used, the technique of checking the validity of data through re-checking and comparing the degree of reliability of information obtained through different sources.

\section{Discussion}

\subsection{Judicial Corruption in Justice System of Law Enforcement on Corruption Judicial Corruption}

Bribery in criminal justice belongs to the term judicial corruption or judicial mafia. The International Commission of Jurists (ICJ) classifies it as an insidious and odious judicial corruption, as stated:

"...of all types of corruption, judicial corruption is perhaps the most insidious and odious because this type of corruption gnaws and destroys a most important pillar of a democratic government. Much has been written about the topic of corruption, but judicial corruption tops

the list of the condemned. Corruption adulterates, clogs, pollutes, perverts and distorts the dispensation of justice".

Judicial corruption in the criminal justice system can be interpreted as a crime committed by law enforcement officers, such as police investigator, public prosecutor, judge, on a case being handled, by plotting the case as if the suspect was innocent, though it is guilty, indeed, it is then plotted as if it was a trifle.

\section{Criminal Justice System in Law Enforcement on Corruption}

The implementation of justice system in law enforcement on corruption as a special court refers to Law Number 8 of 1981 concerning Criminal Procedure Code (KUHAP) and Law Number 31 of 1999 which has been amended by Law Number 20 of 2001 concerning Amendment of Law Number 31 of 1999 concerning Eradication of Corruption Crime. Court examination refers to Law Number 20 of 2003 concerning the Eradication Commission for Criminal Crime and Law Number 46 of 2009 concerning the Corruption Criminal Court inaugurated on April 28th, 2011.

The success of justice system in law enforcement on corruption in enforcing law and justice is highly dependent on the intellectual and moral aspects of law enforcement officers as a major component of law enforcement. If the moral and intellectual of the law enforcement officers are good, they will certainly carry out their duty and authority seriously and fully responsibly. Conversely, if they lack of moral values termed as moral impurity (lack of integrity, selfishness, greed, and temptation, as well as lack of principles and religion), they will tend to lead the law to chaos, dishonesty, and problem.

Concerning fact, the moral and intellectual of law enforcement officers do not get better. They reduce the law as a means of gaining personal benefit. This is the paradox of the criminal justice system in law enforcement on corruption. Judicial corruption has mostly affected law enforcement officers' life by deviating from law enforcement. 


\subsection{The Natures or Forms of Judicial Corruption in Law Enforcement}

The results of the analysis on judicial corruption that causes the paradox of the criminal justice system in law enforcement on corruption are explained as follows:

\section{Disregard of the Law}

The term Disregard of the Law is derived from the word "gampang" (easy) with the addition of suffix and prefix meaning "menganggap enteng" (underestimate/disregard) . Disregard of the law means underestimating the law showing that the mental construction of law enforcement officers is not wholehearted in carrying out their duty and function, as police, prosecutor, or judge, and in enforcing the law (examining and studying deeply). It is common knowledge that corruption erodes the rule of law. Besides, the term also refers to an unwillingness to examine and review the facts deeply associated with their knowledge of criminal law. Another term which has also similar meaning to disregard of the law is cursory generalization meaning a strong desire to simplify something complex .

Disregard of the law is caused by: (a) sluggish mentality which is unwilling to examine the facts or explore a complicated corruption case due to the formal legal perspective understood. In this sense, the officer's knowledge and understanding about criminal law are considered linear and narrow, and the effort to enforce law is formed by the officers' limited knowledge of law in revealing truth and justice; (2) profit-loss or bribery mentality. In this sense, it does not mean the officer has low ability regarding criminal law, but an orientation to the interest of gaining benefit or personal wealth is more dominant in influencing the officers' performance. Such mentality implication assumes that the corrupted officer is very much needed by the suspect or defendant to be asked for relief for his/her mistake. If the suspect or defendant does not bribe the officer for the case, even a simple case can be complicated, instead.

Conversely, if a corruption case is potentially profitable, the officer will manipulate the law to justify the suspect or defendant's crime. Such condition leads the officer's mental and way of thinking to ignore the truth and justice which should actually be the main concern. The implication of disregard of the law in the level of investigation can be seen from the minutes of examination of witnesses, experts, evidence, and incomplete and undetailed legal relations on the corruption case committed. At the level of prosecution, it can be seen from the indictment and claim letters which are considered sufficient to fulfill the indictment, although it does not describe the details of the event that must be revealed from the series of legal relationship of the suspect's action, fault, and accountability from the witnesses and evidence available.

At the trial level, this mentality does not appear because in judging, the judge is not alone, but there are three to five judges. Thus, the mentality of disregard of the law is covered by the other judges in investigation at court, adjudication discussion, or in considering adjudication. At the appeal level, the adjudication of Supreme Court only takes over the legal consideration of first level court's adjudication without giving consideration to aspects of action, fault, and accountability. Supreme Court's adjudication should straighten the essence of the law against matters that are objections to justice seeker, not add to the obscurity by strengthening the adjudication and by taking over the legal consideration of first level court.

\section{Cherry-picking}

The term cherry-picking in law has a negative connotation because it contains an unfair meaning and there is element of favoritism in adjudication of corruptor. It also disregards the equality before the law, the principle that all persons should be treated the same before the law without regard to wealth, social status, or political power . Besides, cherry-picking is also used 
to describe the law enforcement officer's action which abuses power and authority through reasons and formal legal ground for personal interest of gaining personal benefit from the corruption case handled.

Besides, cherry-picking can also be interpreted as two things, namely (1) in the same event; one case is temporarily handled while another one is not, (2) in the same case, a defendant is named a suspect while another one is released. Therefore, from a process standpoint, those who have the right to do cherry-picking is only the police investigator and public prosecutor, while judge do not, because in handling case, judge acts as a recipient of delegation from public prosecutor. The practice of cherry-picking can be carried out by police investigator on a case that will be submitted to the public prosecutor. However, the public prosecutor handling the case can find out because there will always be irregularity or deficiency in the case file regarding the legal subject and its legal relationship with the event involved in the process of corruption such as lack or incomplete suspects submitted.

Likewise, if the cherry-picking is carried out by a public prosecutor, the judge appointed to examine and hear the corruption case can feel and find that there is something wrong in the indictment. In the process of examining at the court, the judge usually knows it. Therefore, the incomplete legal subject will be questioned both to legal subject who is the witness and to the public prosecutor. One of cherry-picking case is on the corruption of special allocation fund of Education Board of the North Lampung District in 2010 which was handled by the Lampung Regional Police. In this case, five suspects were determined, namely the former Head of Education Board of North Lampung District, Chair of the Project Committee, Treasurer of the Office, Official of Technical Implementation Activity (PPTK) of the Physical Development Project, and a civil servant (PNS) in North Lampung. The five suspects were not detained by the Regional Police, but were only required to report every Monday and Thursday. However, in its development, only two suspects were submitted to attorney for trial, namely $Z$ and UM.

\section{Limiting the Legal's Reach}

Limiting or keeping away from the legal's reach can be interpreted that in a criminal event, legal's reach is limited to certain mage, so it cannot reach certain event that should still be related. Limiting legal's reach is a reflection of the legal action of police investigator and or public prosecutor. The difference between the act of limiting the legal's reach and cherrypicking lies in the identity of the legal subject. In the act of limiting or distancing from the legal's reach, the identity of the legal subject is people who have important position or high official and the like. In the act of cherry-picking, the identity of the legal subject does not have to be an important person, but it can be anyone who has economic capacity and access to law enforcement officers.

A concrete case of practice limiting legal's reach can be found in the examination of corruption case in Lampung's East Coast Road (Jalinpatim), Road and Bridge Construction Projects of Lampung Province for the Construction of Roads and Bakauheni Bridges Ketapang - Way Jepara in 2008. The state losses caused were Rp. 25,881,117,762. The public prosecutor in the indictment did not touch the intellectual actors, but only the executors. The judge handling the case could find out by looking at the capacity of the three defendants who were tried only to carry out work based on orders and assignments given by their superiors. The intended civil servant, namely MN (Defendant I), civil servant in the project was appointed as Head of Administrative Affairs and as Holder of Work Advances (Retainer Work). Y (Defendant II), civil servant in the project was appointed as Engineering Administration. H (Defendant III), civil servant who in the project were appointed as Treasurers. 
People who were supposed to be responsible for criminal law, such as the Chairperson of the Land Procurement Committee (P2T) and AH as the Head of the Lampung Provincial Nonspecific Work Unit (SNVT) as the power of budget users were not touched in the public prosecutor's charge. However, in the trial, the dominant role of the two legal subjects was revealed as actors who should be responsible for the activities of the country's projects. But in the prosecutor's charges, the legal's reach of the legal subject was limited to only three defendants.

\section{Narrowing the Meaning of the Law}

Narrowing the meaning of the law can be termed as canalization of the meaning of the law which means an effort to limit the legal meaning to special interests which are usually adjusted to the interest of certain parties. The canalization of legal meaning comes to the surface in the form of differences in legal interpretation, for example the meaning in interpreting the meaning against the law, jointly carrying out deeds, suspending detention, and so forth. Narrowing the meaning of the law tends to refer to the interests of law enforcement actors in constructing or protecting case by using legal themes as symbols. It seems to be part of an event or discourse that has the right, intact, and true meaning.

In a concrete case, narrowing the meaning of the law committed by police investigator can be seen in the case of suspending the detention of corruption suspects which cost the state finances Rp. 1,558,498,420 on routine road maintenance work activities in East Lampung Regency in 2011. DM underwent a two-week detention period, by the police investigator, the detention of a suspect was suspended based on the suspect's request submitted by the attorney for cooperative reasons and with the guarantee that the suspect would not flee and would not remove the evidence. Taking into account the reasons stated, further legal action was taken by issuing a warrant for suspension of detention.

The suspension of DM's detention in the proposition is interpreted by the investigator as a procedural legal action. Corruption crime by police investigators is positioned and interpreted as being similar to conventional crimes, such as mild persecution, unpleasant acts, and so on. The procedural legal argument grants suspension of detention which actively weakens the main objects of corruption crime that is detrimental to state finances and removes people's rights to development and welfare. In some cases of corruption investigation, forced efforts are made through: (a) summons, (b) arrests, (c) detention, flavored profit-loss model legal action as stated by Lawrence M. Friedman and becoming the mode of judicial corruption . This was factual when the DM as the suspect and the legal counsel reported to the Jakarta Police Headquarters that the suspect was extorted by East Lampung Police Investigator .

Substantially, the suspension of detention by police investigator to DM is a canalization of legal meaning, such as the statement of the Chief of Police and the Public Relations of the Lampung Police, "Surely all of them are in accordance with applicable rules and it is the people's right to refuse. More importantly, the police have carried out in accordance with applicable rules". Suspension of appropriate detention is a reflection of legal action in form of narrowing the meaning of the law into a hiding place for profit-loss legal behavior that causes judicial corruption.

\section{Exploiting the Severity of the Sentence}

Exploiting the severity of the sentence implies that the judge in determining action and fault is only based on procedural law. Provisions for the severity of sentence are used and exploited by judges not only to implement procedural law, but also to gain personal benefit by committing judicial corruption (the practice of bribery). The defendant never knows the 
severity of the sentence according to the action and fault made. However, fear and anxiety to lead a life in prison cause the defendant to try to negotiate with the judge through a lawyer or substitute clerk, in essence, to be free or lightly punished by giving bribes.

The judge who knows the severity of the defendant's act, in fact, even though it is a light sentence, but on the grounds of the threat of severe punishment, the judge receives money from the defendant or its family. Conversely, there is also a judge who gives a severe sentence to the defendant because there is no demand for reduced sentence and no promising or giving money. This situation makes the defendant's sentence more severe. According to Guntur Purwanto, judge who is oriented towards material benefit will play at strafmaat (criminal sanctions) imposed. The meaning of playing at strafmaat implies that a judge with such mentality reflects legal action using heavy and light threat or sentence as a mode of gaining economic benefit from the accused.

Provisions on the severity of criminal threat by some law enforcement officers can be exploited or abused to gain material benefits by making statements that incriminate or alleviate the accused / defendant, as if judicially the sentence would be heavy or light. Even though it is done, the reasons for legal consideration tend to be less legal. As in some cases of corruption that the suspect / defendant is a chief of service. In the subjectivity of law as an official (respected person), he/she should be given a heavier sentence for committing a corruption. However, the judge is looking for a reversed legal reason, "Because the defendant as an official and a public figure, being a defendant has borne a heavy burden. Shame is a very severe psychological punishment, so the minimum sentence has been very heavy for him." In essence, the profit judge wants to reduce the serious criminal sentence that is imposed as a light criminal. Personal subjectivity seems to be the reason given by the profit judge.

The profit judge who behaves like that sometimes does not reduce the crime, but tells the lawyer or defendant that the sentence to be handed down has been lowered / alleviated. Therefore, he receives money from the defendant who does not know anything about the sentence. Some of the profit Judges are determined to free the defendant because they see the economic potential faced for any reason, despite overturning the truth.

Though mental and relational process that makes a corrupt act not be seen or rationalized, to improve mental models like that requires multiple physical strengths through changes in mental habits (mindset) which are grouped into three mentalities, namely (1) visionary mentality, the ability to look forward through systemic thinking and breadth of insight, (2) full consistency mentality, a mentality that familiarizes work methods, thought, policy, and action to accumulate knowledge, and structured actions in an effort to achieve greater goal, and (3) a disciplined mentality, consistency between willingness and action to be achieved.

\section{Closing}

Based on the explanation of the discussion above, the conclusions that can be put forward are as follows:

1. The law enforcement of corruption by some police investigators, public prosecutors, and judges in Indonesia has raised the paradox of law enforcement which actually reflects the practice of judicial corruption, not fair law enforcement.

2. The natures and characters of judicial corruption crime are constructed by mental activities that weaken the law enforcement of corruption through legal actions, namely disregard of the law, cherry-picking, limiting the legal's reach, narrowing the meaning of the law, and exploiting the severity of the sentence. 


\section{References}

[1] Bachri, Bachtiar S. 2010. Meyakinkan Validitas Data Melalui Triangulasi pada Penelitian Kualitatif (Convincing Data Validity through Triangulation on Qualitative Research), Education Technology Journal, Volume 10, Number 1, April 2010.

[2] Benito, Bernardino; Guillamon, Maria-Dolores; Rios, Ana-Maria; Bastida, Fransisco. 2018. Can Salaries and Re-election Prevent Political Corruption? An Empirical Evidence. Revista de Contabilidad - Spanish Accounting Review Vol. 21, No. 1, pages 19-27.

[3] Boly, Amadou and Gillanders, Robert. 2018. Anti-corruption, Discretionary Power, and Institutional Quality: An Experimental Analysis. Journal of Economic Behavior and Organization, Vol. 152, pages 314-327.

[4] Denzin, Norman K. and Yvonna S. Lincoln. 2009. (Eds) Handbooks of Qualitative Research, Yogyakarta: Pustaka Pelajar.

[5] Depdiknas. 2008. Kamus Besar Bahasa Indonesia (Indonesia Dictionary); Language Center, 4th Edition, Jakarta: Gramedia Pustaka Utama.

[6] Gault, David Arellano. 2017. Corruption as an Organizational Process: Understanding the Logic of the Denormalization of Corruption. Contaduria y Administracion, Vol. 62, pages 827 842 .

[7] Haryadi, Slamet. 2018. Hukum Pidana Integral, Telaah Kultur Hukum Pencegahan Suap di Kalangan Penegak Hukum (Integral Criminal Law, Review of Law Enforcement of Bribery among Law Enforcement Officer), Yogyakarta: Genta Publishing.

[8] Ida Laode. 2010. Negara Mafia (Mafia Country), Yogyakarta: Galang Press.

[9] Indrayana, Deni. 2008. Negeri Para Mafioso: Hukum Disarang Koruptor (The Land of the Mafioso: Law in the Corps' Nest), Jakarta: Kompas.

[10] Keraf, Gorys. 2010. Argumentasi dan Narasi (Argumentation and Narration), Jakarta: Gramedia.

[11] Koudelkova, Petra and Senichev, Valery. 2015. Mix Research Approach towards Corruption Experts' Perception: Challenges and Limitations. Procedia - Social and Behavioral Sciences, Vol. 175, pages 39-47.

[12] Locatelli, Giorgio; Mariani, Giacomo; Sainati, Tristano; and Greco, Marco. 2017. Corruption in Public Projects and Megaprojects: There is an Elephant in the Room! International Journal of Project Management, Vol. 35, pages 252-268.

[13] Muladi. 1999. Hak Asasi Manusia, Politik dan Sistem Peradilan Pidana (Human Rights, Politics, and the Criminal Justice System), Semarang: BP Undip.

[14] Oleinik, Anton. 2016. Corruption of the Road: A Case Study of Russian Traffic Police. IATSS Research, Vol. 40, pages 19-25.

[15] Othma, Zaleha; Shafie, Rohami; Hamid, Fathilatul Zakimi Abdul. 2014. Corruption - Why do They do it? Procedia - Social and Behavioral Sciences, Vol. 164, pages 248-257.

[16] Reksodiputro, Mardjono, 1994. Kriminologi dan Sistem Peradilan Pidana, Kumpulan Karangan Buku Kedua (Criminology and Criminal Justice System, Second Book Collection), Jakarta: PPKPH UI.

[17] Rohman, Saifur. 2013. Hermeneutik Panduan ke Arah Desain Penelitian dan Analisis (Hermeneutic Guide to the Direction of Research and Analysis), Yogyakarta: Graha Ilmu.

[18] Kristiana, Yudy, Ketika Hukum Tidak Lagi Otentik (When the Law is no longer Authentic), Supremacy Law Journal No IV, Vol 1, 2011..

[19] Piliang, Yasraf Amir. "Parasit Hukum" (Legal Parasites), Kompas, October 16th, 2013.

[20] Sihombing. Sabrina O. 2018. Youth Perceptions toward Corruption and Integrity: Indonesian Context. Kasetsart Journal of Social Sciences, Vol. 39, pages 299-304.

[21] Talvitie, Antti. 2017. Observed Differences in Corruption between Asia and Africa: The Industrial Organization of Corruption and Its Cure. Transportation Research Procedia, Vol. 25, pages $4472-4490$. 
[22] Vazsony, Alexander T. and Jiskrova, Gabriela Ksinan. 2018. On the Development of SelfControl and Deviance from Preschool to Middle Adolescence. Journal of Criminal Justice, Vol. 56, May-June 208, pages 60-69.

[23] International Commision of Jurists, Reviewing Measures to Prevent and Combat Judicial Corruption, The Experience of Lesotho, Justice S. Peete Lesotho Sun International Maseru, July 29th, 2010.

[24] Buron Polres Datangi Sekkab Lamtim (Fugitive of Regional Police Visits Secretary of East Lampung District), Lampos, January 17th, 2013.

[25] DAK Manis Namun Menjerumuskan (The special allocation fund is sweet, but plunging), Lampung Post, December 12th, 2012.

[26] Radar Lampung, April 4th, 2013.

[27] Republika co.id, KPK, 18 governors and 75 regents/mayors caught in corruption, April 17th, 2018.

[28] http://riset.ti.or.id/corruption-perceptions-index-2017/. Accessed on June 29th, 2018.

[29] https://www.republika.co.id/berita/nasional/hukum/18/04/17/p7bfze330-kpk-18-gubernur-dan75-bupatiwali-kota-terseret-korupsi. Accessed on July 2nd, 2018.

[30] https://databoks.katadata.co.id/datapublish/2018/09/05/berapa-anggota-dpr-dan-dprd-yangtertangkap-korupsi. Accessed on July 2nd, 2018.

[31] https://radartegal.com/berita-nasional/lima-tahun-17-hakim-kena-ott-kpk.18992.html

[32] https://www.hukumonline.com/berita/baca/lt5a4dd59fad9f4/kasus-suap-gratifikasimendominasi-di-sidang-sidang-mkh. Accessed on July 2nd, 2018.

Inhabitant Number. 2016. Jakarta. 